\title{
鉄道車両の駆動装置用小歯車軸受の運転状態に影響を及ぼす要因の検討
}

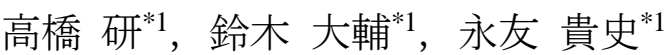

\section{Investigation of factors affecting the performance of pinion bearing for gear unit of railway vehicle}

\author{
Ken TAKAHASHI ${ }^{* 1}$, Daisuke SUZUKI ${ }^{* 1}$ and Takafumi NAGATOMO*1 \\ ${ }^{* 1}$ Railway Technical Research Institute \\ 2-8-38 Hikari-cho, Kokubunji-shi, Tokyo 185-8540, Japan
}

Received: 7 May 2019; Revised: 13 June 2019; Accepted: 16 July 2019

\begin{abstract}
If bearings for gear units of railway vehicles are damaged by seizing, parts of the bearings come off and damage the gear and the gear box, which may lead to the leakage of the gear oil and the defective rotation of the wheel sets. Tapered roller bearings are mostly used in the gear units in Japan. The sliding speeds at the contact surface between the roller end and the inner ring flange of the pinion bearings are higher than that of the gear bearings. In the pinion bearings, therefore, seizure may occur by metal-to-metal contact from inadequate lubrication between the roller end and the inner ring flange. In order to prevent seizure of the bearings and to improve the reliability of the gear units, it is important to clarify the causes of the inadequate lubrication and the mechanism developing from inadequate lubrication into seizure of the bearings. In this work, the effects of bearing rotational speeds and loads, gear oil temperatures and flow rates, and endplay (internal clearance of bearings) values on the performance of the bearings have been investigated by using a rotation testing apparatus for pinion bearings. As a result, it has been clarified that the heating value from bearings increase as the oil temperature decreases and as the oil flow rate increases. In addition, it has been found that the endplay value is greatly reduced when the rotational speed of the bearing rapidly accelerates to high speed under conditions where the temperature of the gear oil is relatively low.
\end{abstract}

Keywords : Railway vehicle, Gear unit, Pinion, Machine element, Tribology, Rolling bearing, Seizure, Gear oil, Endplay

\section{1. 緒言}

鉄道車両（電車）の駆動装置の多くは，継手を介してモータと直結寸る小歯車と車軸に取り付けられる大歯車 から成る平行軸一段減速機であり，その回転部では，歯車箱に対して小歯車軸を支持する小歯車軸受や車軸に対 して歯車箱を支持する大歯車軸受に転がり軸受が使用されている．これらの軸受として，国内では一般に円寸い ころ軸受が用いられており，軸にはめ合わされて回転する内輪，歯車箱に固定される外輪，内輪と外輪の間を転 がりながら荷重を伝達するころ, およびころ同士が接触しないよう等間隔に配置する保持器によって構成される. これらの部品同士の接触部は歯車によってはねかけられるギヤ油により潤滑される(大山，平沢，1996).

これらの軸受の損傷には, 外部からの振動(Evans et al., 2017)による保持器の異常摩耗や, 軸受内部での焼付き に起因するものがあり, 軸受が損傷すると, 軸受を構成する部品が歯車箱内に脱落して歯車や歯車箱を損傷させ, ギヤ油の漏洩や輪軸の回転不整を伴う故障に至る場合がある．なかでも，小歯車軸受の回転速度は大歯車軸受に 比べて高いことから，内輪つば面（以下，つば面とする）ところ大端面のすべり接触部におけるすべり速度も高 く，この部分の潤滑不良を発端として焼付きが進行する場合がある．潤滑不良の要因の一つとして，低温下での ギヤ油の粘度増加による軸受部一の油の供給不足が指摘されており，低温環境に対応するために，主に低温流動 性を向上させたギヤ油の開発が進められてきた(木川他，2018). しかし，エンドプレイ值（小歯車軸を支持する 2 個の軸受の組合せすきまであり，軸受の外輪が固定された状態で，内輪がはめ合わされた小歯車軸を軸方向に押

No.19-00181 [DOI: 10.1299/transjsme.19-00181], J-STAGE Advance Publication date : 24 July, 2019

*1 正員，（公財）鉄道総合技術研究所（下185-8540 東京都国分寺市光町 2-8-38）

E-mail of corresponding author: takahashi.ken.39@ rtri.or.jp 
し引きした際の変位量として得られる值；以下，EP值とする）や軸受内部での荷重の分布など，その他の潤滑不 良の要因に関する検討事例や，駆動装置の信頼性向上に役立つと考えられる，潤滑不良から焼付きに進行する過 程における軸受の挙動に関する知見は少ない.

そこで, 本研究では小歯車軸受（以下，軸受と記述する場合は，すべて小歯車軸受を指す）の信頼性向上に向 けた知見を得るため, 主に, 実物の軸受の回転試験により焼付きの要因を検討し, 種々の回転条件, 潤滑条件, および軸受の組立条件のもとで軸受の温度やトルクなどの挙動を調べた. はじめに, 実際の駆動装置での軸受の 使用環境を考慮し, 温度やトルク，振動などの軸受の特性に影響を与えると考えられる種々の条件を変更させな がら，軸受を回転させることができる装置を製作し，回転試験により焼付き要因を検討した．次に，検討した要 因の中から, 給油条件の影響を調べた. 合わせて, 軸受や周辺部材の温度変化による $\mathrm{EP}$ 值の挙動, ならびに $\mathrm{EP}$ 值の変化に伴う軸受の内部荷重の挙動を調べた.

\section{2. 試験装置}

試験装置の構成を図 1 に示寸，本装置の製作にあたっては，実際の車両での駆動装置の使用環境を考慮し，軸 受に小歯車（はすば歯車）からの反力に相当するラジアル荷重やアキシアル荷重を負荷させつつ，軸受上部から ギヤ油を滴下（歯車によるはねかけ潤滑を模擬）して，小歯車軸の回転速度に相当する主軸回転速度で回転試験 を行えることを設計条件とした．本装置は実駆動装置での軸受間距離と同じ間隔（128 mm）で対向する 2 個の 小歯車軸受を試験軸受として，それらの内輪が取り付けられた主軸（材質：機械構造用合金鋼 SCM440）を，継 手を介してモータで回転させる構造である.一方, 試験軸受の外輪は八ウジング（材質: 機械構造用炭素鋼 S45C) に取り付けられる，八ウジングは軸箱（材質 : S45C またはアルミニウム合金 A5056 ; 寸法, 形状は同一）に取り 付けられ，これらが一体となった試験部全体を，サーボシリンダで主軸に対して垂直方向に押すことによりラジ アル荷重 $F_{r}$ を, 水平方向に押し引きすることによりアキシアル荷重 $F_{a}$ を, それぞれ試験軸受に作用させること ができる. なお，正のアキシアル荷重はサーボシリンダを引く方向の荷重, 負の荷重は押す方向の荷重を示寸. サーボシリンダの出力は制御装置により調整され， $F_{r}$ および $F_{a}$ を一定に保つことができる.また，主軸は支持軸 受によりラジアル方向およびアキシアル方向に支持されるため, $F_{r}$ および $F_{a}$ の反力は支持軸受が負担する. 主軸 の回転速度は最高で $6000 \mathrm{~min}^{-1}$ (加減速時の速度変化率は $50 \mathrm{~min}^{-1} / \mathrm{s}$ ), ラジアル荷重は最大で $7.0 \mathrm{kN}$, アキシアル 荷重は最大で $12.7 \mathrm{kN}$ である.また，八ウジングと軸箱との間に種々の厚さのシムを挟むことにより，2 個の試 験軸受の外輪間の距離を変更し, EP 值を任意に調整できる構造としている. 主軸の両端部には, 支持軸受が設置

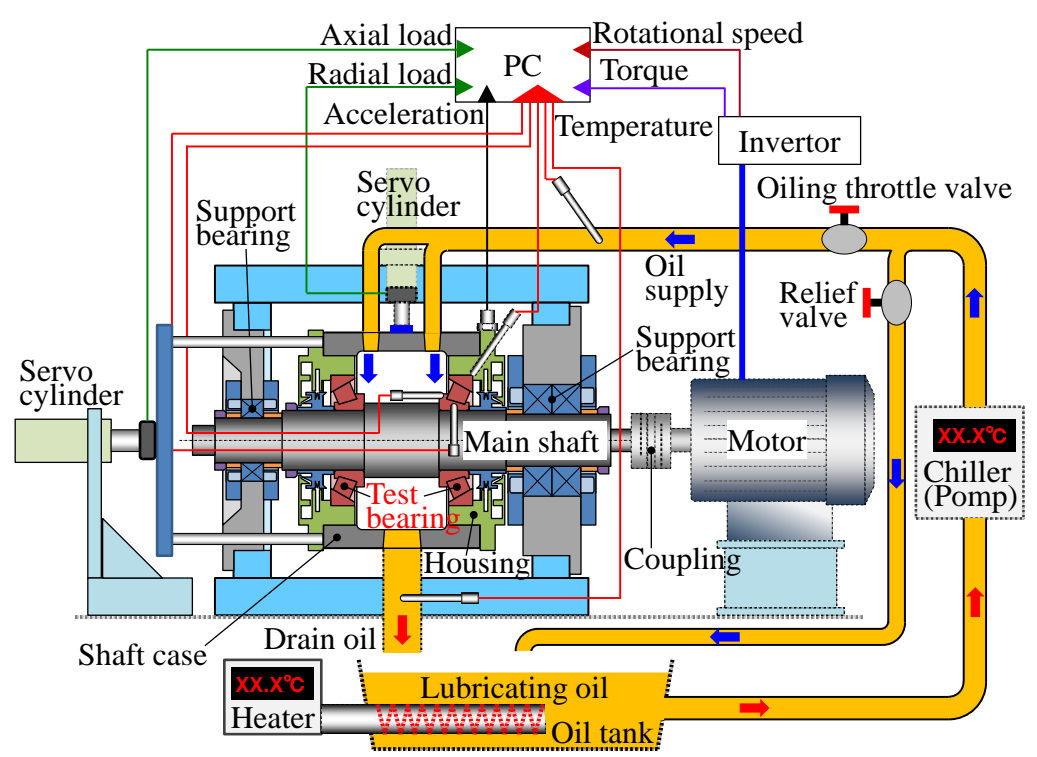

Fig. 1 Schematic view of the rotation testing apparatus for pinion bearings. The test bearings (pinion bearing) attached to the main shaft are rotated by the motor. Radial load and axial load are applied to the test bearings by the electric servo cylinder. The gear oil drips from the top of the bearing. The rotational speed, load, temperature and flow rate of lubricating oil (gear oil) can be changed arbitrarily. 
され，ラジアル荷重およびアキシアル荷重の反力を支持する．ギヤ油はタンクから配管を経由し，試験軸受の上 部に供給され，下部から排出される．また，タンク内のヒータおよび配管途中に設置されるチラーにより, 給油 温度を $5 \sim 50{ }^{\circ} \mathrm{C}$ の範囲で任意に変更できる. なお，ギヤ油はチラーに内蔵されるポンプにより圧送され，配管に 設置された絞り弁およびリリーフ弁を操作することで, 試験軸受部への給油量を 0 ～30 L/min の範囲で調整でき る. 主軸の回転速度およびトルクはインバータからの外部出力により, ラジアル荷重およびアキシアル荷重はロ ードセルにより，それぞれ測定される. 負荷されたラジアル荷重 $F_{r}$ はモータ側と反モータ側の試験軸受に等しく 配分されるため, 試験軸受 1 個当たりのラジアル荷重は $F_{r} / 2$ となる. 図 2 に示寸ように, 試験軸受の温度 $t_{o}, t_{f}$, $t_{r}$ はそれぞれ外輪の外径面，および内輪のつば部と軌道面下（以下，軌道部とする）に設置した $\mathrm{K}$ 型熱電対によ り，軸箱の温度は表面に貼り付けた熱電対により測定される．試験軸受の振動加速度（ $0 \sim 1000 \mathrm{~Hz}$ の実効值）は 八ウジングに設置した圧電式の加速度計により測定される，ギヤ油については，給油温度および排油温度は配管 に設置した熱電対により，給油量（ここでは 2 個の試験軸受で給油量を同一とする）は配管に設置した流量計に より，それぞれ測定される.

試験軸受の諸元を表 1 示寸．試験軸受は，鉄道車両用の小歯車軸受として一般に使用されている円すいころ軸 受であり，その内輪，外輪，ころの材料は高炭素クロム軸受鋼（SUJ2）, 保持器の材料は低炭素鋼板である.

試験に用いたギヤ油の性状を表 2 示す，ギヤ油は，鉄道車両の駆動装置に一般に使用されている鉱油を基油と した潤滑油であり，その動粘度および比熱の温度変化を図 3 に示寸.

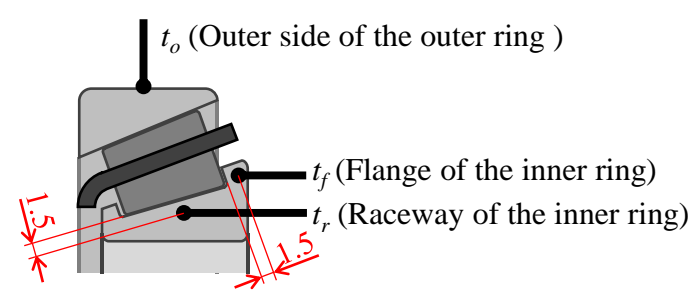

Fig. 2 Temperature measurement positions of test bearing.

Table 1 Principal specifications of test bearings.

\begin{tabular}{|c|c|}
\hline \hline Bearing type & Tapered roller bearing \\
\hline Outside diameter & $150 \mathrm{~mm}$ \\
\hline Bore diameter & $70 \mathrm{~mm}$ \\
\hline Width & $38 \mathrm{~mm}$ \\
\hline Number of rollers & 13 \\
\hline Contact angle & $28.5^{\circ}$ \\
\hline Roller angle & $8.5^{\circ}$ \\
\hline Nominal roller diameter & $21.4 \mathrm{~mm}$ \\
\hline Basic dynamic load rating & $165000 \mathrm{~N}$ \\
\hline
\end{tabular}

Table 2 Principal specifications of gear oil for the test.

\begin{tabular}{|c|c|}
\hline \hline Base oil & Mineral oil \\
\hline Kinetic viscosity $\left(100^{\circ} \mathrm{C}\right)$ & $9.9 \mathrm{~mm}^{2} / \mathrm{s}$ \\
\hline Kinetic viscosity $\left(40^{\circ} \mathrm{C}\right)$ & $78.7 \mathrm{~mm}^{2} / \mathrm{s}$ \\
\hline Viscosity index & 105 \\
\hline Consistency & $890 \mathrm{~kg} / \mathrm{m}^{3}$ \\
\hline Additive & $\begin{array}{c}\text { Extreme pressure additive }(\text { ZnDTP }) \\
\text { Oily formulation }\end{array}$ \\
\hline
\end{tabular}

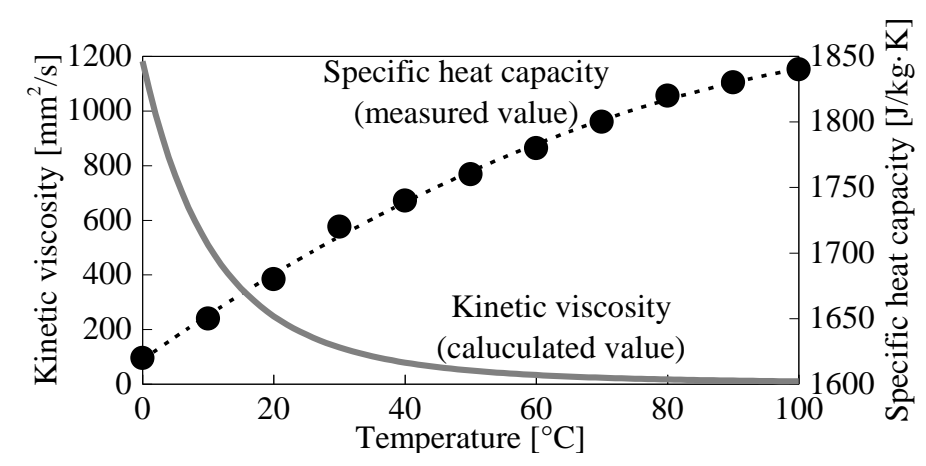

Fig. 3 Property of gear oil for the test. 


\section{3. 軸受の運転状態に影響を及ぼす要因の検討}

軸受の温度や振動などの特性に影響を与えると考えられる各種条件を変更しながら回転試験を行い，軸受の基 礎的な挙動を明らかにする. ここでは, 焼付きの要因となり得る項目として, 軸受の回転速度, 荷重, 給油条件

(給油温度, 給油量), EP 值の 4 点を検討した。測定対象をモー夕側の試験軸受（図 1 参照）として, これらを 変化させながら軸受の回転試験を行った。 なお，ここで用いた軸箱はS45C 製である.

\section{$3 \cdot 1$ 回転速度の影響}

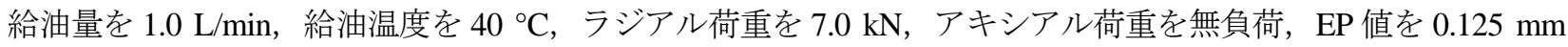
(組立時 $\left(25^{\circ} \mathrm{C}\right)$ の值; 以下, 同様) として, 回転速度を $1000 \mathrm{~min}^{-1}$ から $4000 \mathrm{~min}^{-1}$ まで段階的に増加させなが ら, 軸受のトルク, 温度, および振動加速度を測定した. 図 4 に測定結果の時間経過を示す. 回転速度の増加に 伴い, トルク，軸受温度，振動加速度はいずれも増加する．また，内輪のつば部と軌道部の温度はほぼ同じであ るが，それらの温度は外輪外径面の温度よりも高く，回転速度が高いほどその差が大きくなる．いずれの回転速 度の条件においても, 開始から $120 \mathrm{~min}$ までに各部の温度がほぼ一定となり, 試験装置の系全体が熱平衡に達し たと考えられる.

そこで，これ以降に示す測定結果では特に断りがない限り，一定の試験条件で $120 \mathrm{~min}$ 間回転を続けて得られ る各データについて，その最後の $10 \mathrm{~min}$ 間の平均值を測定值とする.

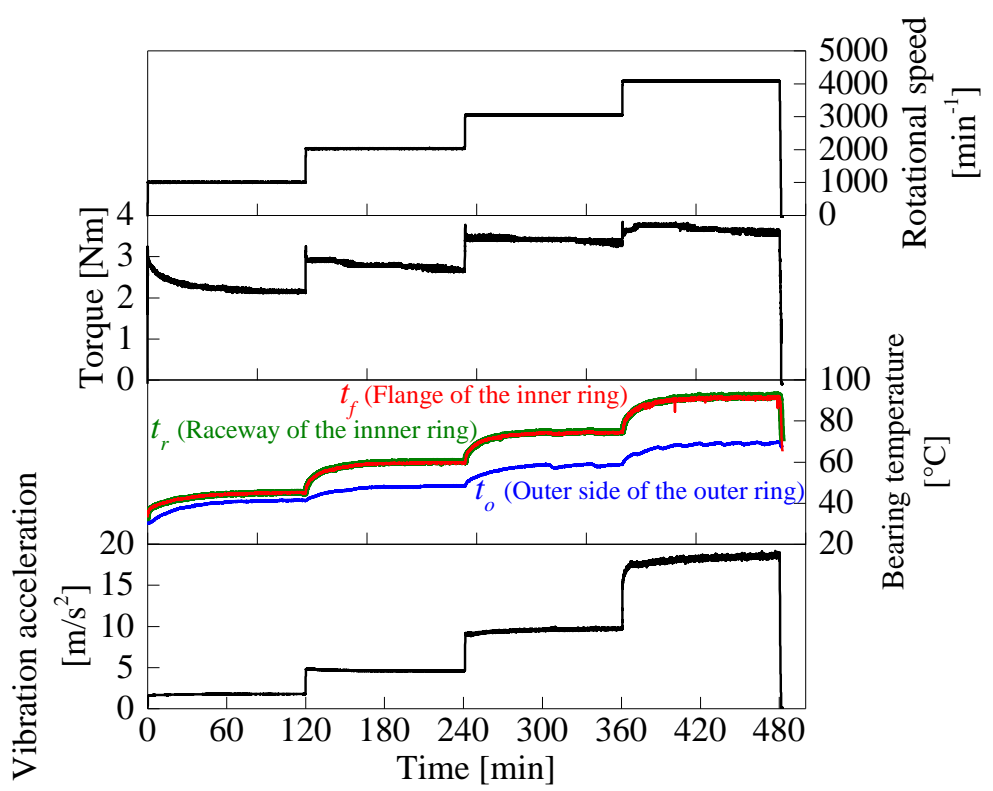

Fig. 4 Effects of rotational speed on the performance of the bearing. As the rotational speed increases, the torque, bearing temperature and vibration acceleration increase. The temperature of the inner ring is higher than the temperature of the outer ring.

\section{$3 \cdot 2$ 荷重の影響}

ラジアル荷重の影響を調べるため, 回転速度を $3000 \mathrm{~min}^{-1}$, 給油量を $1.0 \mathrm{~L} / \mathrm{min}$, 給油温度を $40{ }^{\circ} \mathrm{C}$, アキシアル 荷重を無負荷, EP 值を $0.125 \mathrm{~mm}$ として, ラジアル荷重を $2.0 \mathrm{kN}$ から $7.0 \mathrm{kN}$ まで段階的に増加させながら, 軸受 のトルク，温度，および振動加速度を測定した．図 5 に測定結果を示寸. ラジアル荷重の増加に伴い, トルク, 軸受温度, 振動加速度はいずれも増加する. トルクと軸受温度の増加は, ラジアル荷重の増加に伴う軸受内部で の転がり粘性抵抗の増加や内輪のつば面ところの大端面とのす心゙り接触部の摩擦抵抗の増加によるものと考えら れる.

続いて，一定のラジアル荷重のもとでのアキシアル荷重の影響を調べた．回転速度を $3000 \mathrm{~min}^{-1}$, 給油量を 1.0 $\mathrm{L} / \mathrm{min}$, 給油温度を $40^{\circ} \mathrm{C}$, ラジアル荷重を $7.0 \mathrm{kN}$, EP 值を $0.125 \mathrm{~mm}$ として, アキシアル荷重を- $6.0 \mathrm{kN}$ から $6.0 \mathrm{kN}$ まで段階的に増加させながら，軸受のトルク，温度，および振動加速度を測定した．図 6 に測定結果を示寸.ア 


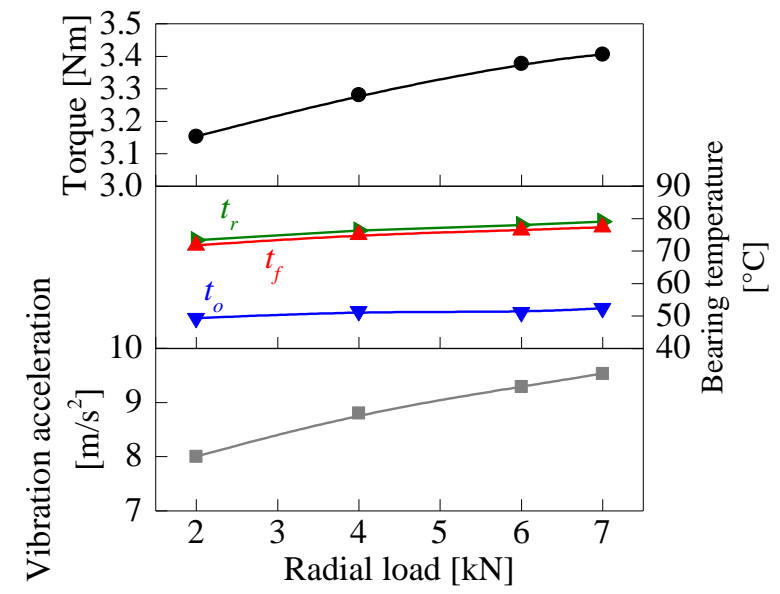

Fig. 5 Effects of radial load on the performance of the bearing. As the radial load increases, the torque, bearing temperature and vibration acceleration increase.

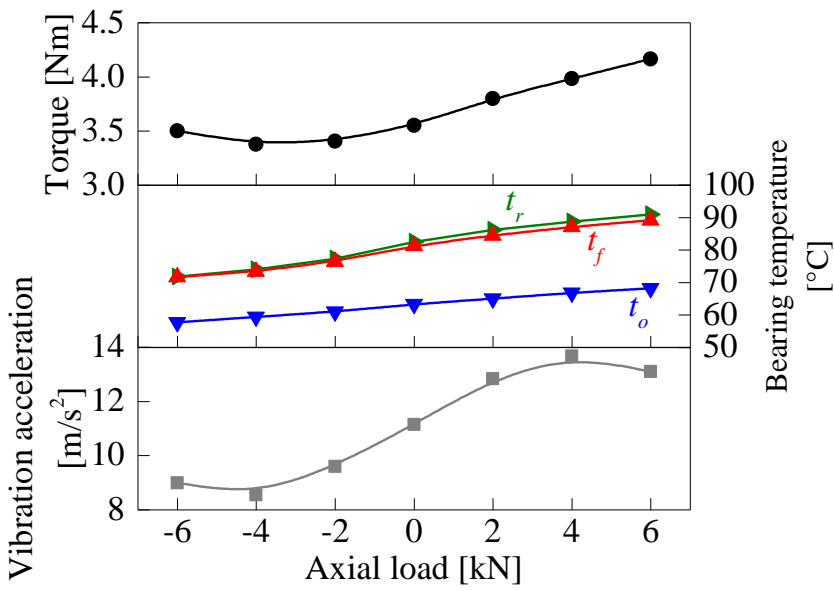

Fig. 6 Effects of axial load on the performance of the bearing. As the axial load increases, the bearing temperature increases.

キシアル荷重の増加に伴い，軸受温度は増加寸る．これは，アキシアル荷重の増加に伴う軸受内部での転がり粘 性抵抗の増加や内輪のつば面ところの大端面との寸心゙り接触部の摩擦抵抗の増加によるものと考えられる. また, アキシアル荷重の増加に伴い, 振動加速度が増加する傾向がみられる.これは, アキシアル荷重の増加により, 内輪のつば面ところの大端面の接触力が増加するためと考えられる.

\section{$3 \cdot 3$ 給油条件の影響}

給油温度の影響を調べるため, 回転速度を $3000 \mathrm{~min}^{-1}$, 給油量を $1.0 \mathrm{~L} / \mathrm{min}$, ラジアル荷重を $7.0 \mathrm{kN}$, アキシア 儿荷重を無負荷, EP 值を $0.125 \mathrm{~mm}$ として, 給油温度を $7{ }^{\circ} \mathrm{C}$ から $50^{\circ} \mathrm{C}$ まで段階的に増加させながら, 軸受の卜 ルク, 温度, および振動加速度を測定した. 図 7 に測定結果を示す. 給油温度が増加するとトルクは低下寸る. これは, 図 3 に示したように温度の増加とともにギヤ油の動粘度が低下したことにより, 軸受内部での転がり粘 性抵抗やギヤ油のかくはん抵抗が減少するためと考えられる．軸受温度は給油温度の上昇とともに上昇する。一 方，振動加速度に大きな変化は見られない．

続いて, 給油量の影響を調べるため, 回転速度を $3000 \mathrm{~min}^{-1}$, 油温度を $40{ }^{\circ} \mathrm{C}$, ラジアル荷重を $7.0 \mathrm{kN}$, アキシ アル荷重を無負荷, EP 值を $0.125 \mathrm{~mm}$ として, 給油量を $0.05 \mathrm{~L} / \mathrm{min}$ から $3.0 \mathrm{~L} / \mathrm{min}$ まで段階的に増加させながら, 軸受のトルク, 温度, および振動加速度を測定した. 図 8 に測定結果を示す. 給油量が増加するとトルクは増加

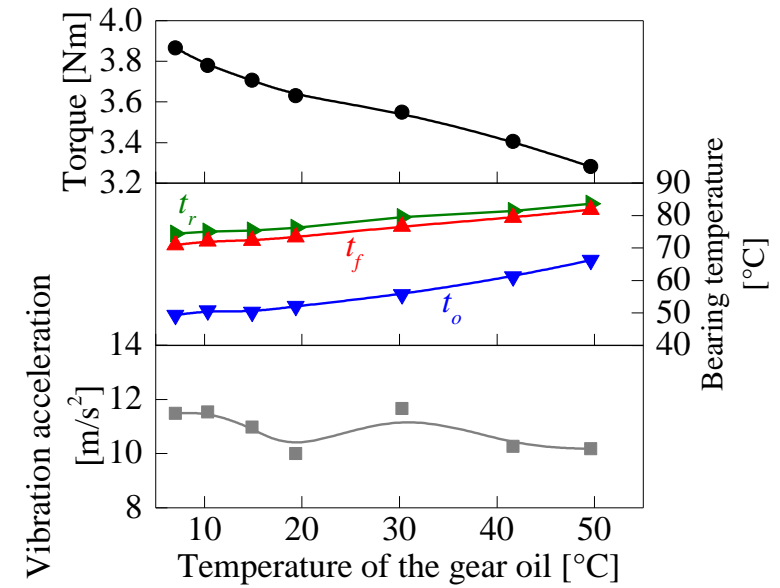

Fig. 7 Effects of temperature of the gear oil on the performance of the bearing. As the temperature of the gear oil increases, the torque decreases and the bearing temperature increases.

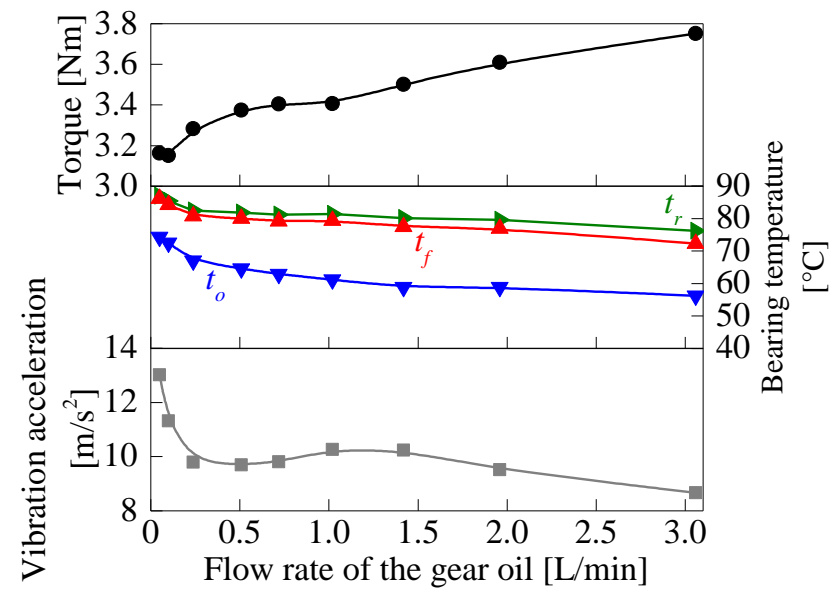

Fig. 8 Effects of flow rate of the gear oil on the performance of the bearing. As the flow rate of the gear oil increases, the torque increases and the bearing temperature decreases. 
する．これは，軸受内部での転がり粘性抵抗やギヤ油のかくはん抵抗が増加するためと考えられる．軸受温度は 給油量の増加とともに低下寸る。これは, 給油量の増加とともにギヤ油による軸受の冷却効果が大きくなるため と考えられる. 振動加速度は給油量が $0.2 \mathrm{~L} / \mathrm{min}$ 以下の非常に少ない範囲で増加寸る傾向にあるが, それ以外の広 い範囲ではほぼ一定である.

\section{$3 \cdot 4$ エンドプレイ (EP) 值の影響}

回転速度を $3000 \mathrm{~min}^{-1}$, 給油量を $1.0 \mathrm{~L} / \mathrm{min}$, 給油温度を $40{ }^{\circ} \mathrm{C}$, ラジアル荷重を $7.0 \mathrm{kN}$, アキシアル荷重を無負 荷として, EP 值を $0.025,0.070,0.125,0.340 \mathrm{~mm}$ と変化させて, 軸受のトルク, 温度, および振動加速度を測 定した. 図 9 に測定結果を示す. いずれの測定値も $\mathrm{EP}$ 值がおおよそ $0.10 \mathrm{~mm}$ を下回ると急激に増加する. 内輪 の温度は外輪より常に 15〜20 K 程度高いため, 軸受やその周辺部材の熱膨張による伸びは, 主軸側が軸箱側より も大きいと考えられる. そのため，組立時の EP 值が小さい条件では，回転中の EP 值がさらに減少することによ り, 軸受のトルクや温度が急激に増加したと考えられる. また, 振動加速度の増加については, 上記の EP 值の 減少により，内輪のつば面ところの大端面とのすべり接触部で部分的に油膜が破断して金属同士が接触すること により, 摩擦係数の変動が生じたことによるものと考えられる.

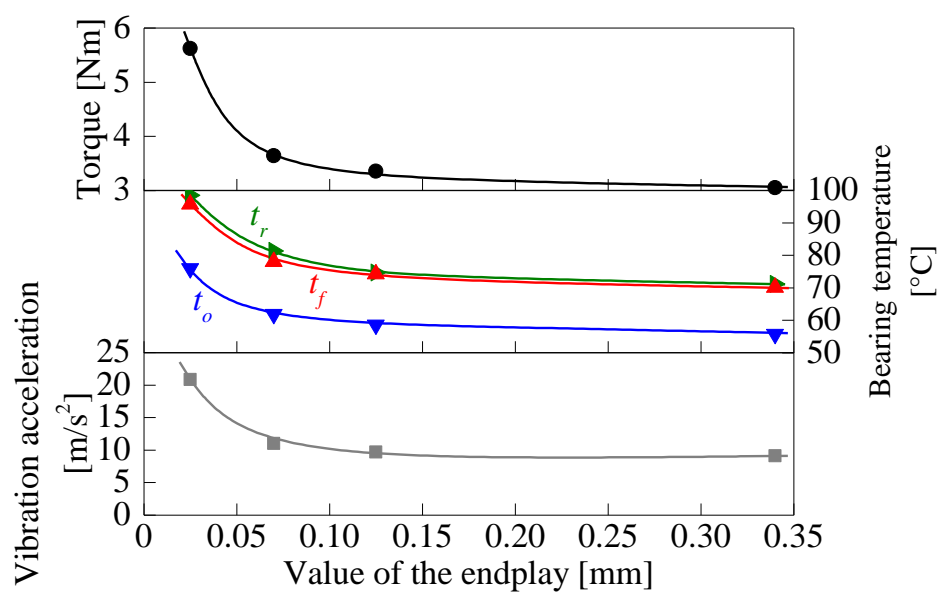

Fig. 9 Effects of the value of the endplay on the performance of the bearing. The torque, bearing temperature and vibration acceleration rapidly increase as the value of the endplay decreases when the value of the endplay is less than $0.10 \mathrm{~mm}$.

以上より, 鉄道車両の速度に依存する軸受の回転速度や, 駆動装置の伝達トルクに依存する軸受の荷重のほか, 給油条件や EP 值の変化が軸受の性能に大きく影響することがわかった. 具体的には, 給油温度の低下, 給油量 の増加, EP 值の減少により, 軸受のトルクは増加する. また, 給油温度の上昇, 給油量の減少, EP 值の減少に より，軸受の温度は上昇する.

\section{4. 給油条件が軸受の発熱および除熱に与える影響}

3 章で軸受の焼付きに影響を与えると考えられる各種の要因について, それぞれが軸受の特性に与える影響を 個別に調べたが，これらのうち，回転速度と荷重は，鉄道車両の設計や諸元に依存するため，ここでは，外部の 環境の影響を受ける可能性がある給油条件についてさらに詳しく調べる.なお，ここで用いた軸箱は S45C 製で ある。

\section{4・1 給油温度および給油量の影響}

\section{$4 \cdot 1 \cdot 1$ 軸受部での発熱量}

回転速度を $3000 \mathrm{~min}^{-1}$, ラジアル荷重を $7.0 \mathrm{kN}$, アキシアル荷重を無負荷, $\mathrm{EP}$ 值を $0.125 \mathrm{~mm}$ とし, 給油温 度と給油量を種々に変化させて回転試験を行い，軸受部での発熱量 $H_{b r g}[\mathrm{~W}]$ を式（1）により求めた。 


$$
H_{b r g}=2 \pi \cdot T \cdot n / 60
$$

ここで， $T$ は主軸のトルク,$n$ は主軸の回転速度である. なお，モータの動力は厳密には支持軸受部での発熱で も消費されるが，支持軸受が試験軸受に比べて小さく，グリース潤滑であることから，試験軸受部に比べると発 熱が十分小さいと考えられるため,ここではモータの動力がすべて試験軸受部での熱に変化したものと見なした.

式（1）により算出した $H_{b r g}$ を図 10 に示す。図は，横軸を給油量，縦軸を給油温度として， $H_{b r g}$ を等值線図で 表したものである。図中の白色部は，振動加速度が急激に増加したため，測定を行わなかった領域である。同じ 給油量で比較すると, 給油温度が低いほど $H_{b r g}$ が増加する傾向が認められる. これは, 給油温度の低下とともに, ギヤ油の動粘度が増加する（図 3 参照）ため, 軸受内部での転がり粘性抵抗やかくはん熱が増加したことによる と考えられる(松山，2015). 一方，同じ給油温度で比較すると，給油量が多いほど $H_{b r g}$ が増加する傾向が認めら れる.これは，給油量の増加とともに軸受内部を通過するギヤ油の流量が増加し，そのかくはん熱が増加したた めと考えられる. なお，給油温度が低く給油量が多い条件（図 10 の右下部）では上記の傾向と異なり， $H_{b r g}$ が著 しく低い。これは動粘度が著しく高いギヤ油が大量に供給されたため，軸受内部へのギヤ油の正常な流入が阻害 され，結果的に軸受内部でかくはんされるギヤ油が著しく減少したためと考えられる.

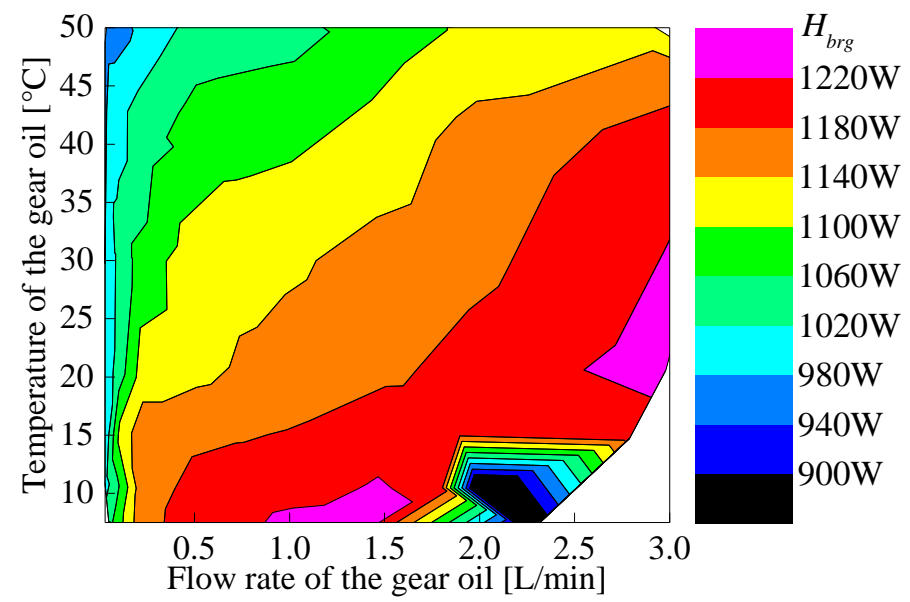

Fig. 10 Heating value from test bearings $\left(H_{b r g}\right) . H_{b r g}$ increases with the decrease in temperature of the gear oil as compared with the same flow rate of the gear oil. $H_{\text {brg }}$ increases with the increase in flow rate of the gear oil as compared with the same temperature of the gear oil.

\section{$4 \cdot 1 \cdot 2$ 軸受部での発熱量}

$4 \cdot 1 ・ 1$ 項に記した回転試験について，ギヤ油による軸受部からの除熱量 $H_{o i l}[\mathrm{~W}]$ を式（2）により求めた.

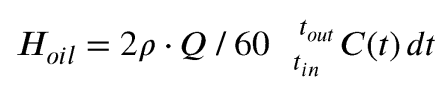

ここで， $\rho$ はギヤ油の密度， $Q$ は給油量， $t_{\text {in }}$ は給油温度， $t_{\text {out }}$ は排油温度， $C(t)$ はギヤ油の比熱である.

式（2）により算出した $H_{o i l}$ を図 11 に示す. $H_{\text {oil }}$ は図 10 に示した $H_{b r g}$ とは一致せず，ギヤ油による除熱だけで は熱収支は均衡しない。これは，試験装置を周囲と完全には断熱していないためであり， $H_{o i l}$ と $H_{b r g}$ の差は，ギ ヤ油を介さず，試験部と周囲との間で直接伝熱（熱伝達や放射）した熱量と考えられる. 給油量が概ね $1.0 \mathrm{~L} / \mathrm{min}$ より少ない条件では， $H_{o i l}$ は主に給油量の増加とともに増加し，1.0 L/min より多い条件では， $H_{o i l}$ は主に給油温度 の低下とともに増加する傾向が認められる．給油量が少ない条件では，給油量の増加とともに軸受内部で高温の 軸受部品の表面と接触するギヤ油量が増加するため， $H_{o i l}$ は給油量の影響を大きく受けたと考えられる．一方， 給油量が多い条件では, 軸受部品の表面と直接接触するギヤ油量は飽和し，それ以上増加しない状態となり， $H_{o i l}$ 


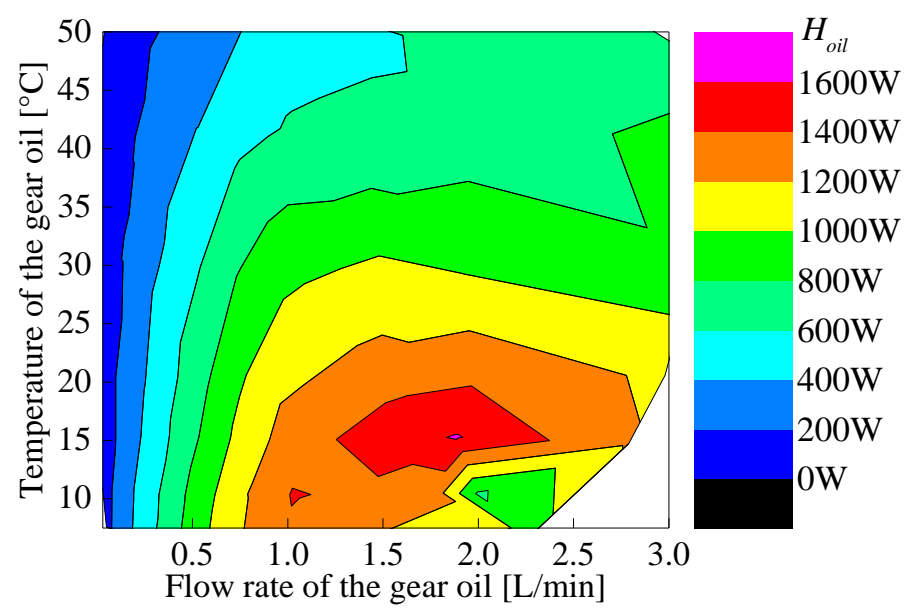

Fig. 11 Exhaust heat to the gear oil $\left(H_{\text {oil }}\right)$. When the flow rate of the gear oil is less than about $1.0 \mathrm{~L} / \mathrm{min}, H_{\text {oil }}$ increases with the increase in flow rate of the gear oil. On the other hand, $H_{\text {oil }}$ increases with the decrease in temperature of the gear oil when the flow rate of the gear oil is more than about $1.0 \mathrm{~L} / \mathrm{min}$.

は給油温度の影響を大きく受けた（給油温度が低いほど，軸受部品との温度差が大きくなる）と考えられるここ のことから，軸受をギヤ油により効率的に冷却するためには，給油量が少ない場合では給油量の増加が，多い場 合では給油温度の低温化が，それぞれ有効であると考えられる. 図 12 に内輪つば部の温度 $t_{f}\left[{ }^{\circ} \mathrm{C}\right]$ を示寸。この図 からも，給油量が少ない場合には，給油温度の低下よりも給油量の増加の方が，軸受の温度低下に与える影響が 大きいことが確認できる.

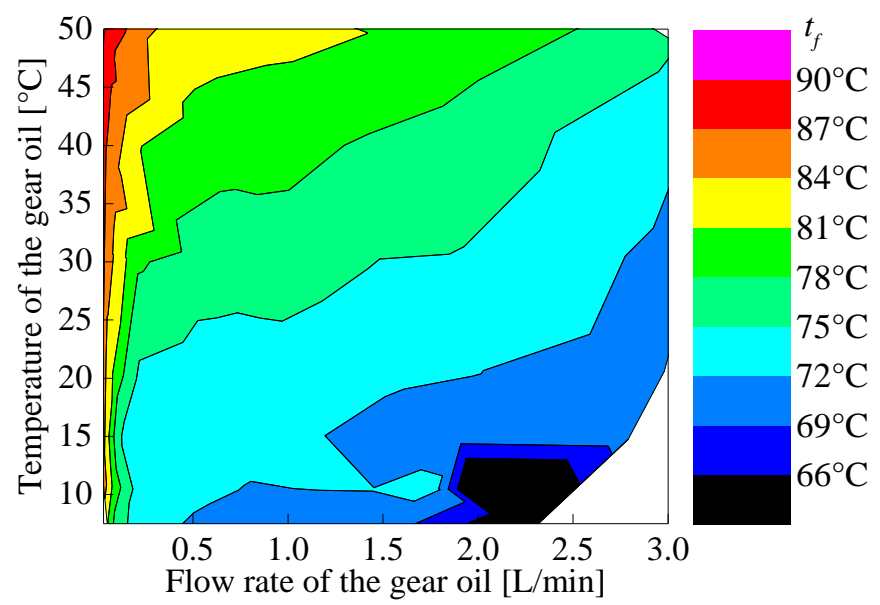

Fig. 12 Temperature of the flange of the inner ring $\left(t_{f}\right)$. When the flow rate of the gear oil is low, $t_{f}$ decreases with the increase in flow rate of the gear oil.

\section{$4 \cdot 1 \cdot 3$ 軸受内部の温度差に関する考察}

図 13 に, 内輪つば部の温度 $t_{f}$ から内輪軌道部の温度 $t_{r}$ を差し引いた值 $t_{f}-t_{r}[\mathrm{~K}]$ を示す．広い範囲で $t_{f}-t_{r}$ は負の 値，すなわち内輪のつば部が軌道部よりも温度が低いことを示しているが，給油温度が低く，かつ給油量が多い 条件（図 12 の右下部）では， $t_{f}$ - $t_{r}$ は正の值となっている.これは, 前述のように軸受内部へのギヤ油の正常な流 入が阻害されたことにより, ギヤ油がつば部に供給されにくくなり, 内輪のつば面ところの大端面とのすべり接 触部で油膜が形成されにくくなったためと考えられる. 上記以外の領域では, 給油温度が高いほど, また給油量 が少ないほど $t_{f}-t_{r}$ が増加する傾向が認められる，給油温度の上昇はギヤ油の動粘度を低下させ，給油量の低下は ギヤ油のつば部への供給量を低下させるため, いずれも内輪のつば面ところの大端面とのすべり接触部の油膜を 減少させて, 潤滑状態を悪化させると考えられる. 


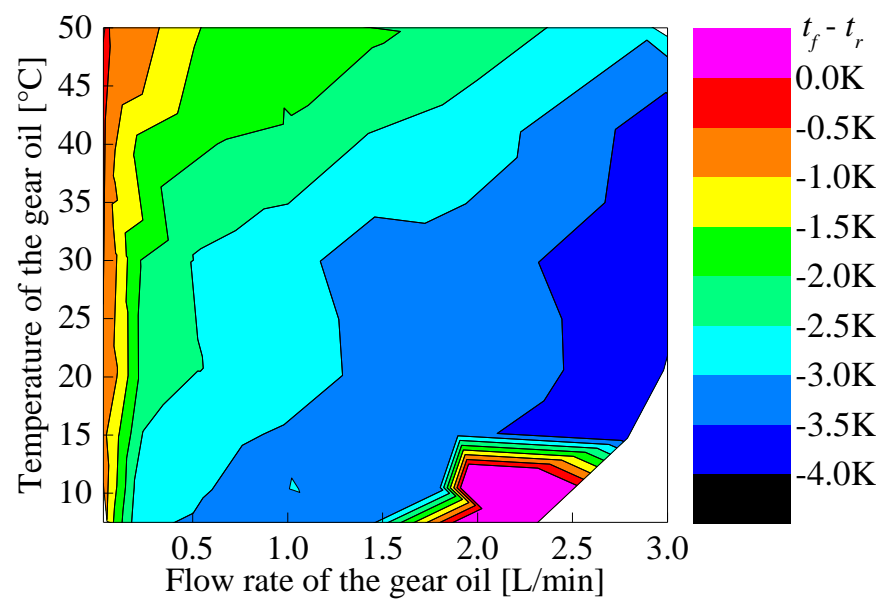

Fig. 13 Temperature difference between the flange and the raceway of the inner ring $\left(t_{f}-t_{r}\right)$. The higher the temperature of the gear oil is, and the smaller the flow rate of the gear oil is, the larger $t_{f}-t_{r}$ becomes.

\section{$4 \cdot 2$ 給油遮断試験}

4 ・1 節では，給油量が少ない場合に，ギヤ油による軸受の冷却作用が低下することや，内輪のつば面ところの 大端面とのすべり接触部の潤滑状態が悪化することがわかった.そこで, さらに給油量が低下した場合を想定し, 給油遮断試験を行った。

試験では，回転速度を $3000 \mathrm{~min}^{-1}$, 給油量を $3.0 \mathrm{~L} / \mathrm{min}$, 給油温度を $30^{\circ} \mathrm{C}$ ，ラジアル荷重を $7.0 \mathrm{kN，アキシアル}$ 荷重を無負荷, EP 值を $0.125 \mathrm{~mm}$ として, 試験装置の系全体が熱平衡に達した状態から, 給油量を減少させて, その約 $40 \mathrm{~s}$ 後に給油を完全に遮断した。なお，試験軸受を損傷させないために，給油を遮断してから $120 \mathrm{~s}$ 後に 試験を打ち切った。困 14 に，各測定值の時間経過を示す。試験打ち切りの $300 \mathrm{~s}$ 前を $0 \mathrm{~s}$ とて示している. 給 油量を減少させると, トルクが低下し, 内輪つば部の温度が上昇する。これは, 図 8 に示した傾向と一致する. 次に，給油を遮断するとトルクはさらに低下するが，変動が大きくなる傾向が認められる．これは，給油遮断に より，軸受内部での転がり粘性抵抗やかくはん抵抗が減少するものの，内輪のつば面ところの大端面とのすべり 接触部で部分的に油膜が破断して，金属同士の接触が生じたためと考えられる。また，内輪つば部の温度上昇は 大きくなるが，内輪軌道部の温度上昇はつば部よりも緩慢であるため， $t_{f}-t_{r}$ は増加する. さらに，軸受部の振動

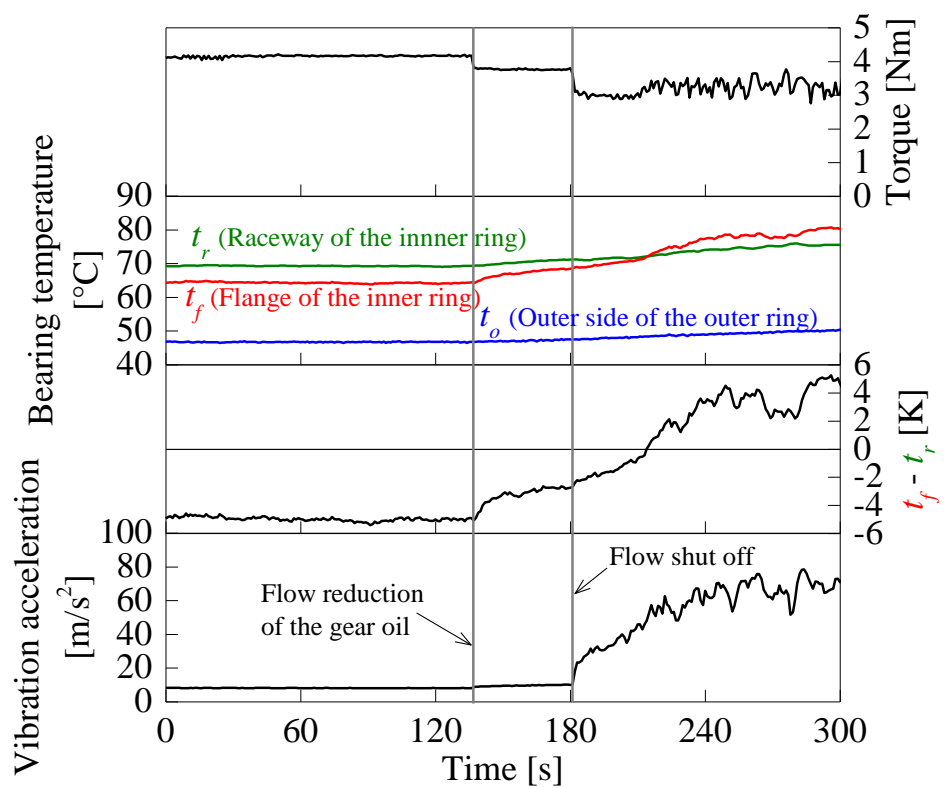

Fig. 14 Behavior of the bearing at the time of flow of the gear oil shutting off. The torque decreases, but its fluctuation increases. The temperature of the flange rises more rapidly than temperature of the raceway of the inner ring. The vibration acceleration of the bearing increases. 
加速度が急激に増加し，その変動も大きくなる．これらについても，内輪のつば面ところの大端面とのすべり接 触部で油膜が破断したことによるものと考えられる.

以上のように, 給油を遮断すると, 内輪のつば面ところの大端面とのすべり接触部の潤滑状態が悪化して, ト ルクは不安定になり, 内輪つば部の温度や軸受部の振動加速度が増加することがわかった.

\section{5. エンドプレイ值の挙動}

4 章では, 内輪のつば面ところの大端面とのすべり接触部における油膜の状態が軸受の挙動に大きく影響する ことがわかった. 内輪のつば面ところの大端面の寸べり接触部の接触状態に影響を与える因子として，4 章で述 べた給油条件のほか，EP值も考えられる．図 9 に示した, EP 值が軸受の特性に与える影響は, 組立時の EP 值 に対して, 試験装置の系全体が熱平衡に達した後の軸受のトルクや温度などの傾向を示したものである.しかし, 実際に走行する鉄道車両では, 駆動装置は様々な環境条件のもとで加減速を繰り返すため, 装置の温度が過渡的 な状態のもとでの EP 值の挙動も把握する必要がある. ここでは, 停止状態から軸受を回転させ, 軸受やその周 辺部材の温度変化と $\mathrm{EP}$ 值の変化の関係を調べる. なお, 軸箱の材質によりその熱膨張率が異なり, EP 值の挙動 に影響を与えると考えられるため,ここでは S45C 製と A5056 製の 2 種類の軸箱を使用した.

\section{$5 \cdot 1$ エンドプレイ值の測定方法および計算方法}

\section{$5 \cdot 1 \cdot 1$ エンドプレイ值の測定方法}

図 15 に軸受の回転中に EP 值を測定する方法を示寸. 軸箱に固定されたアキシアル荷重負荷用の治具にレーザ 変位計（繰り返し測定精度 : $5 \times 10^{-5} \mathrm{~mm}$ ) を主軸の軸端に向けて設置した. 回転試験中に, 一定時間（1１0 min） おきに, 図 16 に示寸負荷パターンで試験部にアキシアル荷重を負荷し, アキシアル荷重が正の時と負の時のレー ザ変位計の出力值の各平均值の差を $\mathrm{EP}$ 值の測定值とする.
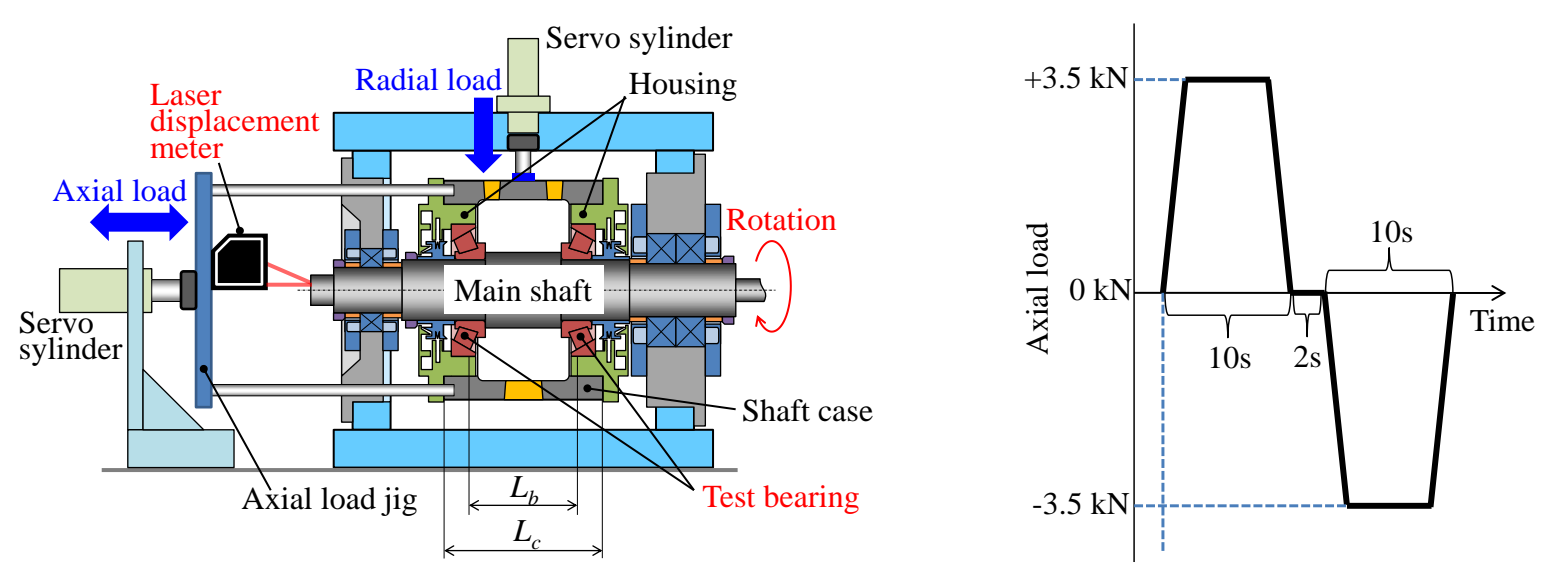

Fig. 15 Schematic view of the measurement of endplay values. Fig. 16 Load pattern during the measurement of endplay values.

\section{$5 \cdot 1 \cdot 2$ エンドプレイ值の計算方法}

部材の軸方向の膨張のみを考慮した式（3）により EP 值を簡易的に算出する.

$$
E P=E P_{0}+\left(t_{c}-t_{a}\right) \cdot \alpha_{c} \cdot L_{c}-\left(t_{h}-t_{a}\right) \cdot \alpha_{h} \cdot\left(L_{c}-L_{b}\right)-\left(t_{s}-t_{a}\right) \cdot \alpha_{s} \cdot L_{b}
$$

ここで, $E P_{0}$ は組立時の $\mathrm{EP}$ 值, $t_{a}$ は組立時の室温, $t_{c}$ は軸箱の温度, $t_{h}$ は軸受ふたの温度, $t_{s}$ は主軸の温度, $\alpha_{c}$

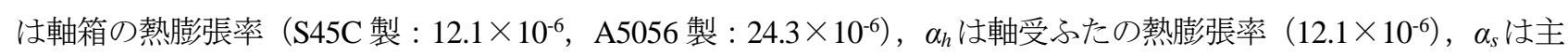

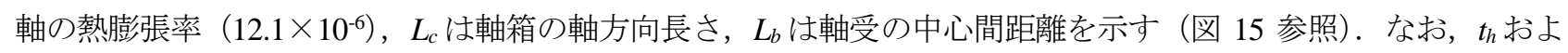
び $t_{s}$ は直接測定していないため, 軸受ふたおよび主軸の近傍である, 2 個の試験軸受の外輪外径面の温度 $t_{o}$ の平 均值および 2 個の試験軸受の内輪軌道部の温度 $t_{r}$ の平均值を, それぞれ用いる. 


\section{5 - 2 軸受と周辺部材の温度変化によるエンドプレイ值の変化}

ここでの試験条件は，給油量を $1.0 \mathrm{~L} / \mathrm{min}$ ，ラジアル荷重を $7.0 \mathrm{kN}$ ，アキシアル荷重を無負荷（ただし，EP值 の測定中の夕短時間負荷), 組立時の $\mathrm{EP}$ 值を $0.105 \mathrm{~mm}$ として, 給油温度と最高回転速度を変化させた. 各試験 において，停止状態で給油のみを行い，試験装置各部の温度がほぼ平衡状態となった後に，回転速度を目標とす る最高回転速度まで増加させ，その後は一定に保つ。試験時間は，回転開始から60 min 間である。

困 17 に，最高回転速度を $3000 \mathrm{~min}^{-1}$, 給油温度を $30^{\circ} \mathrm{C}$ とた条件で試験した結果を，試験軸箱の材質ごとに 示す．横軸は回転開始からの時間を，縦軸は各部の温度と EP 值をそれぞれ示す.S45C 製軸箱では，回転開始直 後に EP 值が減少し, その後はほぼ一定となっている. これは，軸受の回転に伴い主軸の温度 $t_{s}$ と軸箱の温度 $t_{c}$ がともに上昇するものの， $t_{s}$ の方が上昇の程度が大きいため，主軸の熱膨張が軸箱の熱膨張より大きくなったこ とによる.A5056 製軸箱では，S45C 製の場合と同じく回転開始直後に EP 值が減少するものの，約 10 ２0 min の間で EP 值は増加し，その後はほぼ一定となっている。A5056 製軸箱は SCM440 製の主軸より熱膨張率が大き いため，上述の約 10〜20 min の間では，軸箱の膨張量が主軸の膨張量を上回ったと考えられる. これらの測定值 の変化の傾向は計算值とほぼ一致しており，両者の差は最大で $0.02 \mathrm{~mm}$ 程度である.このことから，式（3）に 示した部材の軸方向の膨張のみを考慮した簡易的な計算によって, EP 值を比較的精度よく推定できることがわか つた.

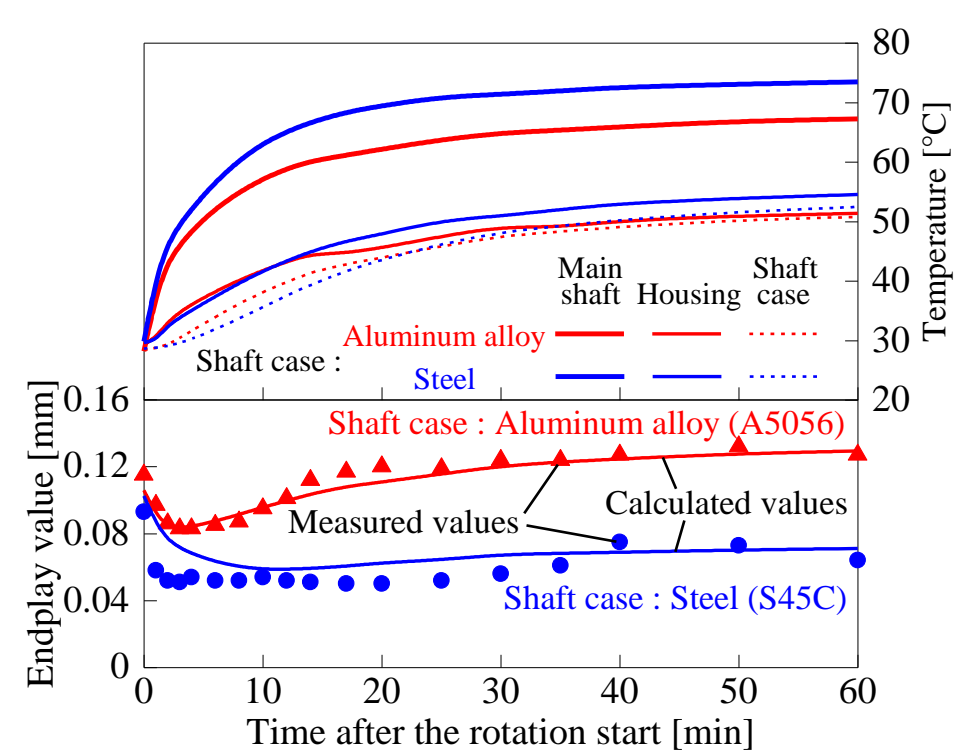

Fig. 17 Change in temperature and endplay. In the steel (S45C) shaft case, the endplay value decreases immediately after the start of rotation, and thereafter becomes almost constant. In the aluminum alloy (A5056) shaft case, the endplay value decreases immediately after the start of rotation and then gradually increases.

図 18 に，最高回転速度を $3000 \mathrm{~min}^{-1}$ とし，給油温度を変化させた場合の EP 值を示す。同図（a）が S45C 製軸 箱での結果，（b）が A5056 製軸箱での結果である.A5056 製軸箱の場合，回転開始時（0 min）における EP 值が 給油温度により異なるが，これは主軸と軸箱の熱膨張率が異なるためである．いずれの軸箱においても，EP值は 給油温度が低いほど小さく, 給油温度が $10{ }^{\circ} \mathrm{C}$ の場合には, 最小で $0.04 \mathrm{~mm}$ 程度まで減少している.また, S45C 製軸箱の場合には回転開始から約 $10 \mathrm{~min}$ 間, A5056 製軸箱の場合には回転開始から約 $3 \mathrm{~min}$ 間, EP值は減少する. 試験終了時の EP 值は, S45C 製軸箱よりも A5056 製軸箱で大きくなっており, 特に給油温度が $50{ }^{\circ} \mathrm{C} の$ 場合には, 約 $0.15 \mathrm{~mm}$ まで増加している.

以上より, 給油温度が低いほど，軸受の回転開始後の EP 值の減少の程度が大きくなることがわかった．EP值 が $0 \mathrm{~mm}$ に近づくと, 軸受の内部で正常な潤滑や荷重の状態が保てなくなる可能性があるため, どのような条件

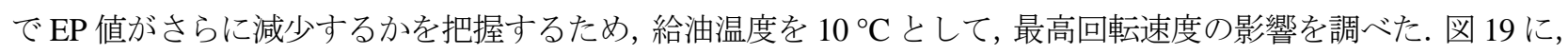
最高回転速度を変化させた場合の EP 值を示す。同図（a）が S45C 製軸箱での結果，（b）が A5056 製軸箱での結 果である.いずれの軸箱においても, EP 值の最小值は最高回転速度が高いほど小さく, 最高回転速度が $4000 \mathrm{~min}^{-1}$ 


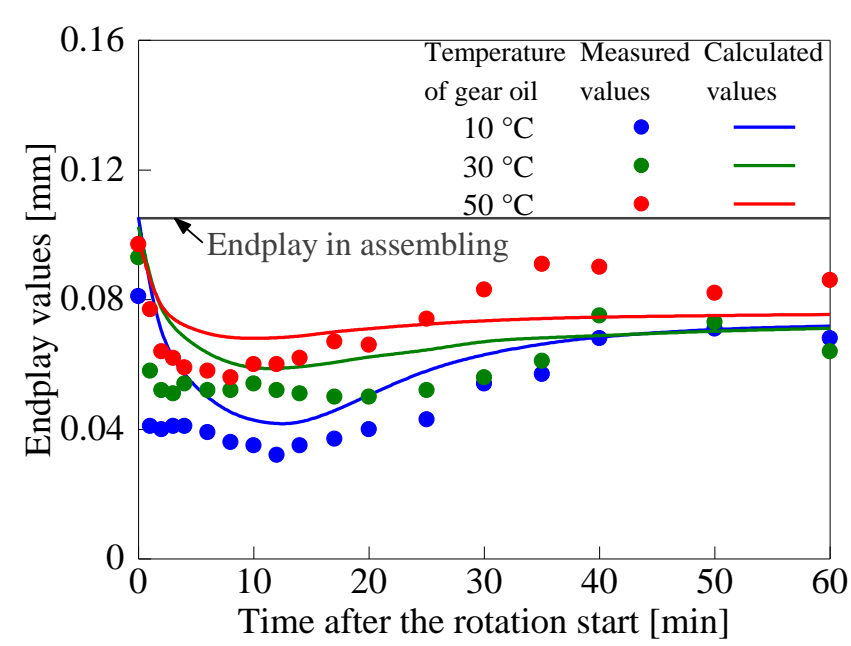

(a) Shaft case : Steel (S45C)

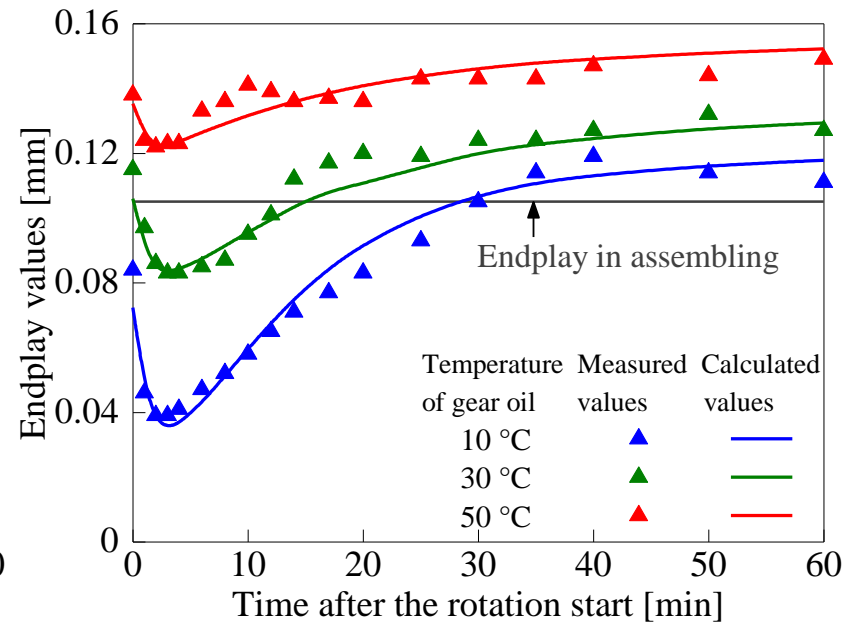

(b) Shaft case : Aluminum alloy (A5056)

Fig. 18 Change in endplay after the rotation start at $3000 \mathrm{~min}^{-1}$ of maximum rotation speed. In both shaft cases, the endplay value decreases as temperature of gear oil decreases, and decreases to about $0.04 \mathrm{~mm}$ at a minimum when temperature of gear oil is $10{ }^{\circ} \mathrm{C}$. The endplay value at the end of the test is larger in the aluminum alloy shaft case than in the steel shaft case.

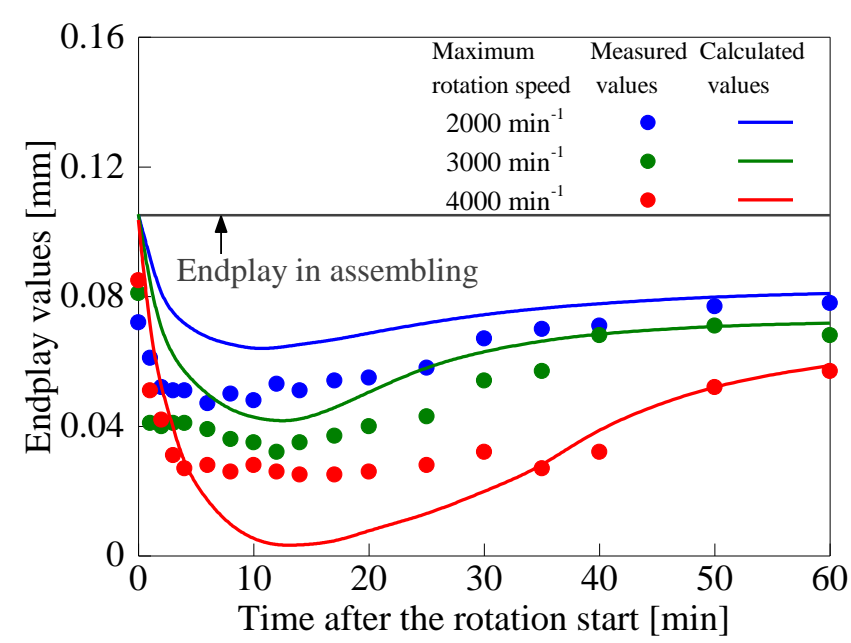

(a) Shaft case : Steel (S45C)

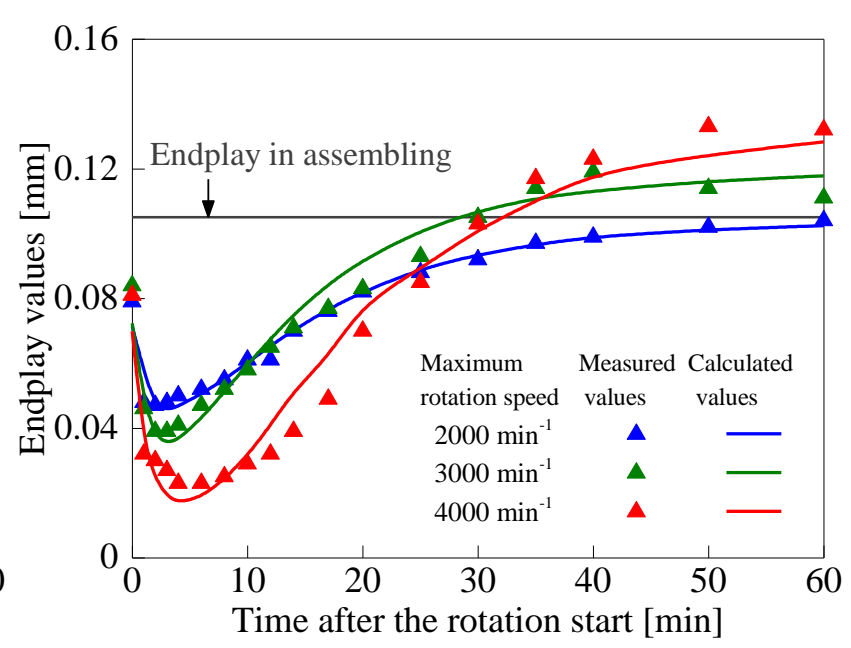

(b) Shaft case : Aluminum alloy (A5056)

Fig. 19 Change in endplay after the rotation start at $10{ }^{\circ} \mathrm{C}$ of gear oil temperature. In both shaft cases, the minimum value of endplay is smaller as the maximum rotation speed is higher. The higher the maximum rotation speed is, the larger is the change in endplay value.

の場合には最小で $0.02 \mathrm{~mm}$ (測定值) 程度である.また，最高回転速度が高いほど EP 值の変動が大きい傾向があ り，特に軸箱が A5056 製の場合，最高回転速度が $4000 \mathrm{~min}^{-1}$ で約 $0.02 \mathrm{~mm}$ から約 $0.14 \mathrm{~mm}$ まで変化している. な お，図 18 および図 19 のいずれにおいても，軸箱が A5056 製の場合に比べ，S45C 製の場合には測定值と計算值 のずれが大きい傾向が認められる。これは，S45Cの熱伝導率が A5056よりも小さいことから，S45C製の軸箱で は，各部での温度の差が比較的大きくなり，軸箱全体として熱膨張が均一にならなかったためと考えられる。

実際の駆動装置と本試験機とでは，回転条件の他に，歯車の有無や各部品の熱容量など様々な違いがあり，部 材の温度変化が異なることに留意しなければならないが，本試験結果から，実際の鉄道車両においても比較的低 温の環境下で, 停止状態から高速域まで短時間で加速する際に，軸受や周辺部材の温度が急激に変化して EP 值 が最も減少すると考えられる. 


\section{6. 軸受内部の荷重分布}

5 章で示したように，軸受の回転に伴う部材の温度変化により EP 值は様々に変化する. EP 值が変化すると, 軸受の内部荷重の状態も変化すると考えられる．そこで， EP 值と軸受の内部荷重の関係を調べる．なお，ここで 用いた軸箱は S45C 製である.

\section{$6 \cdot 1$ 軸受内部荷重の測定方法}

ここでは, 図 1 に示した試験装置のモータ側の試験軸受を荷重測定用軸受とした. 図 20 に示すように, 測定用 軸受の内輪には，軌道面とつば面にそれぞれの母線方向に平行な溝状の切欠き（A および B）を円周方向に $180^{\circ}$ 対向する位置に設けている.これらの切欠きの底部にひずみゲージを接着した．軸受を回転させて，ころが切欠 き $\mathrm{A}$ 部を通過する際に発生するひずみにより，ころから軌道面へ作用する荷重（以下，軌道面荷重 $Q_{i}$ とする） を(田中，1972), 切欠き $\mathrm{B}$ 部を通過する際に発生するひずみによりころからつば面へ作用する荷重（以下，つば 面荷重 $Q_{f}$ とする）をそれぞれ測定することができる．なお，それぞれのひずみゲージは予め，軸受に複数の既知 の純アキシアル荷重を負荷し，全てのころに均等な荷重が発生する条件で回転させることにより，ひずみと荷重 の関係を校正している.

測定においては，給油量を $1.0 \mathrm{~L} / \mathrm{min}$ ，ラジアル荷重を $10.0 \mathrm{kN}$ ，アキシアル荷重を無負荷とし，測定中の温度 変化による組立時からの $\mathrm{EP}$ 值の変化を抑制するため, 回転速度を比較的低速の $500 \mathrm{~min}^{-1}$, 給油温度を室温と同 じとした． EP 值は， $5 ・ 2$ 節で測定された值の範囲の下限に近い $0.025 \mathrm{~mm}$ と上限に近い $0.125 \mathrm{~mm}$ に加え，上限 を大きく上回る $0.340 \mathrm{~mm} の 3$ 種類である．なお，ラジアル荷重は試験装置の最大值である $7.0 \mathrm{kN}$ を超過してい るが，測定を短時間で行うため問題はない.

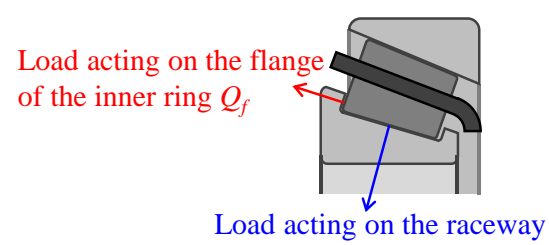
of the inner ring $Q_{i}$

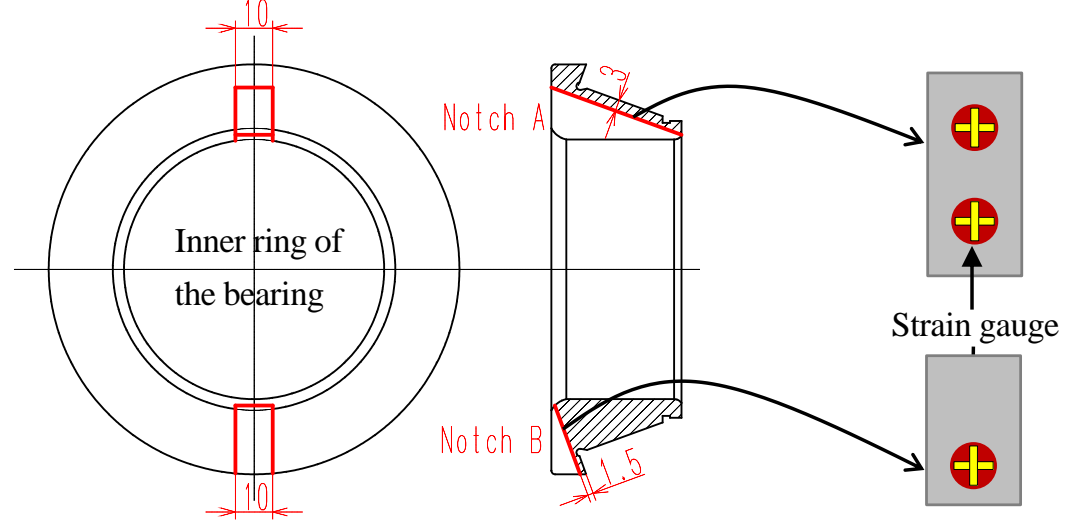

Fig. 20 Schematic view of the measurement of internal load of the bearing. Loads acting on the raceway and the flange of the inner ring from the rollers are measured by strain gauges attached to the inner ring.

\section{$6 \cdot 2$ エンドプレイ值が内部荷重に与える影響}

内部荷重の測定結果を図 21 に示す．同図（a）が軌道面荷重 $Q_{i}, \quad$ (b) がつば面荷重 $Q_{f}$ である．横軸に示すころ 位置は，ラジアル荷重による負荷圈（ころが荷重を受ける範囲）の中心位置（軸箱の直上を向く位置）を $0^{\circ}$, 左 端を-90 ㅇ，右端を 90 ○として，ころの進行方向が正の值となるように示している．なお，非負荷圈となる-180。 〜-90`および $90^{\circ} \sim 180^{\circ}$ の範囲ではすべての測定結果において荷重がほぼ 0 であったため図中では省略している. いずれの EP 值においても，軌道面荷重とつば面荷重は，0○の転動体位置を中心としてほぼ左右対称な山型の分 布を呈している．軌道面荷重とつば面荷重のいずれについても，その負荷圈の範囲は EP 值の増加とともに狭く

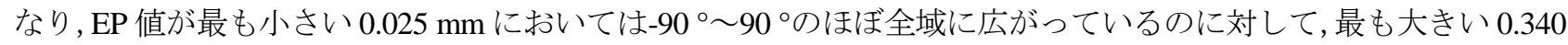
$\mathrm{mm}$ においては- $60^{\circ} \sim 60$ 程度まで狭まっている. また, 軌道面荷重は EP 值が大きいほど, その最大值が大きく なる傾向が認められる．この傾向は，円すいころ軸受の内部すきまと転動体荷重の関係に関する過去の研究結果 (高橋他, 2016) とも一致する. 一方, つば面荷重の最大值は, EP 值が最小の $0.025 \mathrm{~mm}$ で最も大きく, EP 值が 0.125 $\mathrm{mm}$ と $0.340 \mathrm{~mm}$ ではいずれもそれより小さい. 外輪および内輪からころに作用する力は, それぞれの力が作用す 


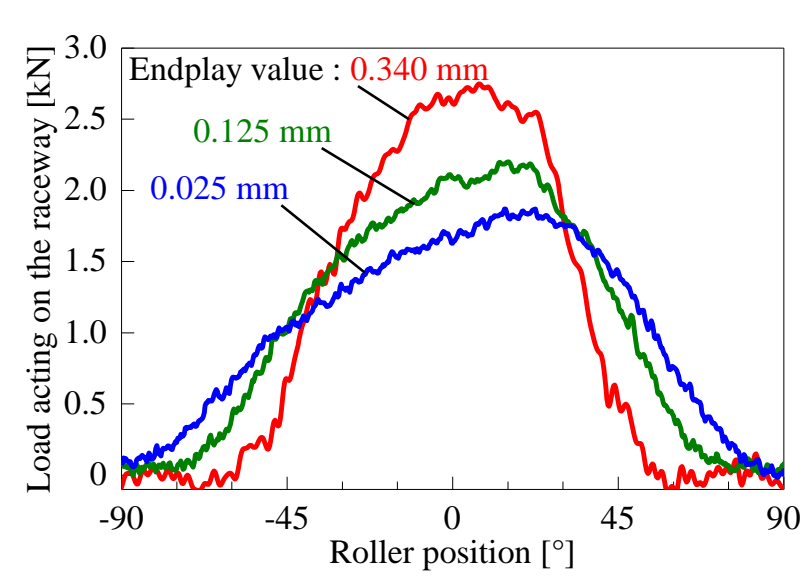

(a) Load acting on the raceway of the inner ring

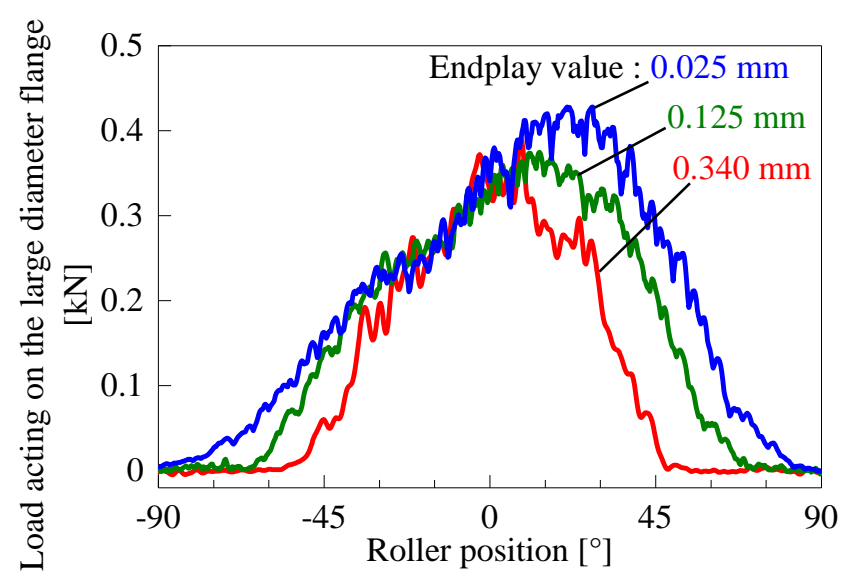

(b) Load acting on the flange of the inner ring

Fig. 21 Effect of endplay value on the internal load of the bearing. The range of the load zone becomes narrower as the endplay value becomes large. The maximum load acting on the raceway becomes larger as the endplay value becomes large. On the other hand, the maximum load acting on the flange is the largest at the $0.025 \mathrm{~mm}$ of the endplay value.

る接触面の角度によって発生するラジアル方向およびアキシアル方向の分力がそれぞれ釣り合うため，理論上， 軌道面荷重とつば面荷重は一定の比率で比例するはずであるが，上述のように図 21 (b) で示されたつば面荷重 の大小関係は，同図（a）で示された軌道面荷重の大小関係と一致していない．EP值が $0.025 \mathrm{~mm}$ や $0.125 \mathrm{~mm} の$ 場合では, 測定值が理論值よりも大きくなっていると考えられる. その原因として, 回転中のころの姿勢の変化, 切欠き B 部を通過するころと隣接するころによるつばのわずかな変形の影響のほか, 測定誤差などが考えられる が, 詳細については今後の検討が必要である.

以下では, 軸受内部荷重の負荷圈の大きさを示寸負荷率 $\varepsilon$ について考察する. $\varepsilon$ は負荷圈の半分の角度 $\varphi_{0}$ を用 いて次式により表される.

$$
\varepsilon=\frac{1}{2} \cdot\left(1-\cos \varphi_{0}\right)
$$

式（4）に，図 21（a） から読み取れる負荷圈の角度 $2 \varphi_{0}$ を代入し， $\varepsilon$ (測定值) を得る. ここでは負荷圈である ことを判断するためのしきい值を，軌道面荷重の最大值 $Q_{\text {imax }}$ を用いて， $0.1 Q_{\text {imax }}$ とする.

一方, Sjövall によって与えられたラジアル積分 $J_{r}(\varepsilon)$ ( Sjövall, 1933), および Palmgren の線接触における弾性変 位の理論(Palmgren, 1964)を用いると，本測定における組合せすきま（EP 值） $\Delta_{a}$ と負荷率 $\varepsilon$ の間には以下の関係が 成り立つ(高橋他, 2016).

$$
\Delta_{a}=7.68 \times 10^{-5} \cdot\left(\frac{1-2 \varepsilon}{\varepsilon} \cdot J_{r}(\varepsilon)^{-0.9}\right) \cdot{\frac{F_{r h}}{Z}}^{0.9} \cdot L_{e f f}^{-0.8} \cdot \cos ^{-1.9} \alpha \cdot \cot \alpha
$$

ここで, $F_{r h}$ は測定用軸受が負担するラジアル荷重 (ここでは, $5.0 \mathrm{kN}$ とする.),$Z$ はころ数, $L_{\text {eff }}$ はころ有効長さ, $\alpha$ は接触角である. 式 (5) から得られる $\varepsilon$ (理論值) と EP 值の関係と, 式 (4) から得られる $\varepsilon$ (測定值) を比 較して図 22 に示す. 測定值は理論值に対し, 負荷率が大きい結果となった. 寸なわち, 測定結果における負荷圈 は理論から求まる負荷圈と比較して, その範囲が広い. この原因として, 切欠き溝 $\mathrm{A}$ の幅に対応する角度分の誤 差や, 本測定においてはラジアル荷重の負荷により軸受の外輪が変形し, 真円形状からのずれが大きくなること に加え, 測定誤差が考えられる. 


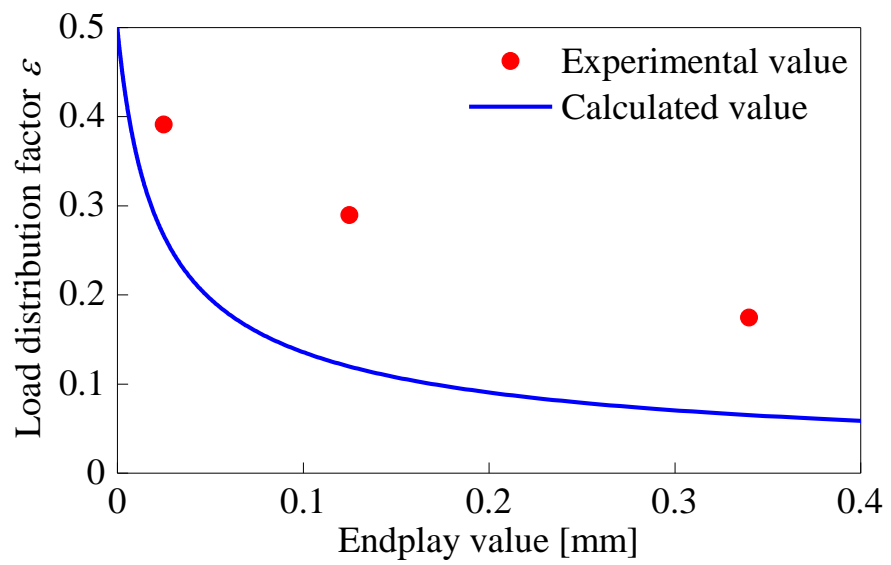

Fig. 22 Comparison of calculated and experimental values of load distribution factor. The experimental value is larger than the calculated value.

\section{7. 結言}

本研究により得られた知見を以下に要約する.

(1) 軸受の焼付き要因を検討した結果, 給油条件や EP 值の変化が軸受の特性に大きく影響することがわかった. 給油温度の低下，給油量の増加，EP值の減少により，軸受のトルクは増加するままた，給油温度の上昇，給 油量の減少, EP 值の減少により, 軸受の温度は上昇する.

(2) 軸受部での発熱量 $H_{b r g}$ について調べた結果，同じ給油量で比較すると，給油温度が低いほど $H_{b r g}$ が増加する 傾向や，同じ給油温度で比較すると，給油量が多いほど $H_{b r g}$ が増加する傾向が認められた.

(3) ギヤ油による軸受部からの除熱量 $H_{\text {oil }}$ について調べた結果，給油量が概ね $1.0 \mathrm{~L} / \mathrm{min} よ り$ 少ない条件では， $H_{\text {oil }}$ は主に給油量の増加とともに増加し，1.0 L/min より多い条件では， $H_{\text {oil }}$ は主に給油温度の低下とともに増加す る傾向が認められた。このことから，軸受をギヤ油により効率的に冷却するためには，給油量が少ない場合 には給油量の増加が，多い場合には給油温度の低温化が，それぞれ有効であると考えられる。

(4) 内輪のつば部と軌道部の温度差について調べた結果や, 給油遮断試験の結果から, 内輪のつば面ところの大 端面とのすべり接触部の油膜形成が抑制されると，つば部の温度が軌道部の温度に比べて相対的に高くなる ことがわかった。

(5) 過渡的な温度の状態のもとでの EP 值の挙動を調べた結果，給油温度が低いほど，また，最高回転速度が高い ほど，軸受の回転開始後における EP 值の減少の程度が大きくなることがわかった。このことから，実際の鉄 道車両においても比較的低温の環境下で，停止状態から高速域まで短時間で加速する際に，EP值が最も減少 すると考えられる.

\section{文献}

Evans, D. R., Houpert, L., Scandella, F., Wilmer, G. M., Klaehn, T. and Buchanan, D. A., Dynamic analysis of rail gearbox bearings, Proceedings of the Institution of Mechanical Engineers, Part F : Journal of Rail and Rapid Transit, Vol.231, Issue 8 (2017), pp.991-996.

木川定之, 鈴村淳一, 沓掛久志, 低温流動性を向上した新幹線車両用ギヤ油の開発, 鉄道総研報告, Vol. 32, No. 10 (2018), pp.23-28.

松山博樹，円すいころ軸受の摩擦トルクの予測ならびに低減技術，トライボロジスト，Vol. 60, No. 9 (2015), pp.24-31.

大山忠夫，平沢弘太郎，鉄道車両用軸受の変遷(3)，鉄道車両と技術, Vol. 2, No.11 (1996), pp.20-27.

Palmgren, A., Grundlagen der wälzlagertechnik (1964), Franckh'sche Verlagshandlung Stuttgart.

Sjövall, H., The load distribution within ball and roller bearings under given external radial and axial load, Tek Tidskr, Mek., Vol.h, No.9 (1933).

高橋研, 鈴木大輔, 永友貴史, 複列円すいころ軸受の転動体荷重に与える内部すきまの影響, 日本機械学会論文 
集, Vol. 82, No. 840 (2016), DOI:10.1299/transjsme.16-00205.

田中克彦, 円寸いころ軸受の実働荷重測定(第 1 報), 潤滑, Vol.17, No.1 (1972), pp.45-52.

\section{References}

Evans, D. R., Houpert, L., Scandella, F., Wilmer, G. M., Klaehn, T. and Buchanan, D. A., Dynamic analysis of rail gearbox bearings, Proceedings of the Institution of Mechanical Engineers, Part F : Journal of Rail and Rapid Transit, Vol.231, Issue 8 (2017), pp.991-996.

Kikawa, S., Suzumura, J. and Kutsukake, H., Development of a gear oil with improved low-temperature fluidity for Shinkansen electric cars, RTRI REPORT, Vol. 32, No. 10 (2018), pp.23-28(in Japanese).

Matsuyama, H., Prediction and reduction technologies of friction torque for tapered roller bearings, JOURNAL OF JAPANESE SOCIETY OF TRIBOLOGISTS, Vol. 60, No. 9 (2015), pp.24-31(in Japanese).

Oyama, T. and Hirasawa, K., Development of bearings for railway vehicles (3), Rolling Stock \& Technology, Vol. 2, No.11 (1996), pp.20-27(in Japanese).

Palmgren, A., Grundlagen der wälzlagertechnik (1964), Franckh’sche Verlagshandlung Stuttgart.

Sjövall, H., The load distribution within ball and roller bearings under given external radial and axial load, Tek Tidskr, Mek., Vol.h, No.9 (1933).

Takahashi, K., Suzuki, D. and Nagatomo, T., Effect of internal clearance on rolling element load of double row tapered roller bearings, Transactions of the JSME (in Japanese), Vol. 82, No. 840 (2016), DOI:10.1299/transjsme.16-00205.

Tanaka, K., A practical method for measuring service loads on tapered roller bearings (Part 1), Journal of Japan Society of Lubrication Engineers, Vol.17, No.1 (1972), pp.45-52(in Japanese). 